\title{
THE CULTURAL SIGNIFICANCE AND ISLAMIC VALUES OF GUGON TUHON
}

\author{
Favorita Kurwidaria ${ }^{1}$, Astiana Ajeng Rahadini, SF. Lukfianka Sanjaya \\ Purnama ${ }^{2}$ and Bagus Wahyu Setyawan ${ }^{3}$ \\ ${ }^{1}$ Universitas Sebelas Maret \\ ${ }^{2}$ Institut Agama Islam Negeri Surakarta \\ ${ }^{3}$ Institut Agama Islam Negeri Tulungagung \\ Email: favorita@staff.uns.ac.id
}

\section{Abstrak}

This research focused on studying gugon tuhon in Surakarta and its relation to Islamic values. The gugon tuhon was related to the marriage cycle, pregnancy cycle, and children family education. The data were obtained through interview with the Javanese society in Surakarta area. It employed an interactive analysis with the cultural interpretation relevant to Islamic values. The result indicates that some gugon tuhon in the marriage include prohibition for brides to go out by themselves and conduct wedding ceremonies in Sura/Muharram month. In the pregnancy cycle of gugon tuhon, pregnant women are prohibited from gossip and think negatively since those result in the child personality. Husbands of pregnant women are also prohibited from killing or hurt animals because their children will be harmed. The gugon tuhon in educating children includes the prohibition to go out at Maghrib (sunset prayer) because an evil spirit will kidnap them and suggestion to washing hands and legs before visiting babies. The existence of gugon tuhon can be used as the character education to construct good habits. Besides, gugon tuhon functions to implant Islamic moral values in terms of tolerance, responsibility, and good deeds to build a harmonious life system.

Penelitian ini mengkaji gugon tuhon di Surakarta dan kaitannya dengan nilainilai keislaman. Gugon tuhon yang dikaji adalah dalam siklus pernikahan, siklus kehamilan, dan yang digunakan untuk mendidik anak. Data diperoleh 
dari hasil wawancara dengan masyarakat di wilayah karesidenan Surakarta. Analisis interaktif digunakan dengan pemaknaan secara kultural selanjutnya direlevansikan dengan nilai islami. Hasil penelitian menunjukkan beberapa gugon tuhon dalam perkawinan, diantaranya adalah larangan calon penganten putri untuk bepergian sendiri dan larangan untuk melaksanakan pernikahan di bulan Sura/Muharram. Dalam gugon tuhon siklus kehamilan, wanita hamil dilarang menggunjing dan berpikiran negatif karena akan berdampak pada watak anaknya. Suami yang istrinya sedang hamil juga dilarang membunuh dan menyakiti hewan karena anaknya akan celaka. Gugon tuhon dalam mendidik anak seperti larangan untuk keluar di waktu Magrib karena akan diculik oleh wewe gombel dan anjuran untuk membasuh kaki-tangan sebelum bertemu dengan bayi. Adanya gugon tuhon dapat digunakan sebagai sarana pendidikan karakter kepada generasi muda untuk membentuk kebiasaan-kebiasaan yang baik. Selain itu, fungsi gugon tuhon juga sebagai sarana menanamkan nilai-nilai moral keislaman seperti tenggang rasa, toleransi, tanggung jawab, dan selalu berbuat baik kepada sesama untuk membentuk sistem kehidupan masyarakat yang harmonis

Keywords: cultural significance; gugon tuhon; Islamic values; Javanese society

\section{Introduction}

Javanese people have a view of life always to be able to maintain a balance and harmony between individual, society, the universe and the creator. They believe that the universe is the source of various necessities of life so that humans need to seek balance with nature to avoid distress (Roibin, 2010). This effort is reflected in their various cultural forms and traditions. Various cultural forms, physical, non-physical, verbal, and written, contain noble values that can better regulate human life (Setyawan \& Saddhono, 2017). One of culture realization in Javanese society is oral tradition. The oral tradition is a belief inherited from generation to generation. It is in terms of command, suggestion, prohibition, or way of life that society needs to obey. There are some oral traditions in Javanese culture such as folklore, legend, gugon tuhon, wewaler, etc.

Oral traditions in Javanese society function to pass down cultural knowledge and values that the local community believes to be true (Soehardi, 2002). One of the forms of oral tradition which is still often found in Javanese society, especially in Surakarta, is Gugon Tuhon. Etymologically, gugon tuhon is derived from gugon and tuhon. According to Bausastra Jawa dictionary, the 
word gugon is a derivative word from the word gugu that gets a suffix -an which has the meaning of believing in people's words. Meanwhile, the word tuhon is a derivative form of the word tuhu which gets a suffix -an and has a loyal or loyal meaning. Thus, gugon tuhon means words that must be obeyed faithfully (Poerwadarminta, 1939). The existence of gugon tuhon in the Javanese society has some particular functions. Some gugon tuhon contains a teaching not revealed (not explicitly disclosed), but disguised Subalidinata (1968: 13). Consequently, society needs to look for the meaning or message delivered by this gugon tuhon. Form of gugon tuhon usually is a prohibition that contains disguised teaching. If the prohibition is not obeyed or the teaching is not implemented it will cause difficulties or disadvantages (Kurniawati \& Widhyasmaramurti, 2019).

Javanese parents often using the form of gugon tuhon in advising their descendants from generation to generation. The purpose of advising gugon tuhon is to easily obey the advice, commands or prohibitions from their parents. Surely these suggestions and advice follow the values and norms that exist and apply in society, and are for their good (Sundari, 2018). The formulation of gugon tuhon concept does not merely formulate an event without observation. Gugon Tuhon is formulated based on the ngelmu titen (observing the phenomena) or the process of observation of things that often occur repeatedly, and bad effects that may entail if it is not implemented (Ekowati, 2008). The ngelmu titen is obtained by studying events or natural phenomena repetitively and continuously in a certain period. This makes the Javanese society construct a concept from repetitive natural phenomena with the term of ngelmu titen or a science obtained through observing and analyzing repetitive natural phenomena.

In this current era as technology advances, this form of oral tradition such as gugon tuhon is often regarded as irrational and even old-fashioned superstitions and fictions by some people, especially the younger generation (Taruna, 2016). This is due to that many members of the society consider the concept of gugon tuhon is not relevant to be applied in the technology era. All predictions and consequences of the gugon tuhon are only superstitions. The influence of other cultures also makes gugon tuhon unpopular or even disregarded by the Javanese society. Scholars consider the gugon tuhon as an irrational knowledge since it is not supported by sciences possibly accepted by logic. Some religious circles consider the gugon tuhon as polytheistic because of believing in the ones except the One Almighty God. The existence of the Islamic view that tends to be radical increasingly makes local cultures such as gugon tuhon unaccepted. While this situation keeps happening, the concept 
of gugon tuhon will become disappear, and the Javanese society will not believe in this concept.

The concept of gugon tuhon contains some messages and great values of the Javanese culture if it is deeply investigated. These values can construct the discipline character from the Javanese society who always respects the existence of the universe. The universe and everything in it is God's word that needs to be read and learned to be used as facilities to strengthen belief and god-fearing. The suggestion to always think or use mind in viewing natural phenomena is also found in Q.S. an-Nahl: 12, "And He has subjected for you the night and day and the sun and moon, and his command subjects the stars. Indeed, in that there are signs for people who reason." Besides, it is also stated in Q.S. Ali "Imran: 190, "Indeed in the creation of the heavens and the earth and the alternation of the night and the day are signs for those understanding."

These two verses clarify that the One Almighty God, Allah, has given signs and commemorations to humans through natural phenomena such as day and night, air, wind flow, cloud movement and some society's habits. In applying the concept of ngelmu titen to make a gugon tuhon, Javanese ancestors always observe natural phenomena repetitively and happen in a long time. It indicates that the concept of ngelmu titen is the implication of those two Quran verses regarding using the mind to translate natural phenomena created by Allah.

In fact, there have been many studies revealing myths and their relations to religious knowledge. These researches become rationale in this article to reveal a theme about the relevance of gugon tuhon in Surakarta City to Islamic values in the society. Kholik (2019) found that the myths and beliefs in marriage prohibition in the Javanese society became allowed as long as they were compatible with Islamic lessons and were considered legal. Wahyuni (2018) identified that the prohibition against conducting wedding ceremonies in Tahun Duda was viewed from the urf method, so this tradition was considered the 'urf fasid. The tradition of prohibiting marriage in Tahun Duda was not for good but would cause mafsadhat for the society particularly in Pati regency. These researches show the strong relevance between myths and Islamic religious knowledge. These definitely strengthen Javanese myths, and the gugon tuhon can be accepted by Islamic religion since it does not deviate from tauhid lesson (the concept of monotheism).

Myths and gugon tuhon truly contains knowledge of Islamic values and morals. Andariati (2019) found that Pemali River myths made the society 
believed in supernatural strength in Pemali River which positively affected their attitudes in treating Pemali River. Hence, the society is actually being responsible as Allah's caliphate. Similarly, another study from Indiana, Makmum \& Machmudah (2019) also indicated the relevance of culture and religion. The ruwahan tradition in Ngendut Village at Jombang city implies society's tauhid knowledge that the purpose of conducting the ruwahan ceremony by visiting pesarean (grave) is not only to make the tradition demand but also to remind the society about death. Hence, they have to prepare good deeds to face hisab.

The relation between gugon tuhon culture and Islamic values of the society were investigated more deeply in this article. It aimed to reveal the Islamic values of gugon tuhon culture in the Javanese society. This article attempts to logically describe the gugon tuhon culture by relating it to Javanese society's Islamic values.

\section{Gugon Tuhon as an Oral Tradition}

In entering the Javanese society, Islam manages to culturally integrate with Javanese culture (Ali, 2011). The relationship between tradition and religion has been able to live harmoniously for hundreds of years. Tradition and religion in fact have the same vision of achieving the good of human life. Both are well received and then embodied in various actions, both based on belief and religion (Fitri, 2012). In Javanese society there are still, undeniably, some forms of oral traditions that have not yet been rationally accepted. However, the purpose of the oral tradition, including gugon tuhon, is to provide education to future generations to have good intellect, ethics, and morality in harmony with society and the environment.

Gugon tuhon is one of the forms of oral tradition because there is no authentic text containing the contents of gugon tuhon. Like other oral traditions, gugon tuhon is spread by word of mouth and passed down across generations. Regarding oral tradition characteristics, Muraina (2015) provides the following findings that oral tradition is a story, tradition, or practice shared orally or through speech- usually handed down from generation to generation. Oral tradition is usually eventually written down, but can tell us so much about the society and the people who originated them and allowed history to be kept and shared by groups who do or did not have writing (Kamilah \& Setyani, 2018).

The statement illustrates the characteristics of the oral tradition which gugon tuhon also has. Thus, it can be said that gugon tuhon belongs to the type of oral tradition. Furthermore Nurdin (2016) includes the form of gugon tuhon 
as part of myth. Myth can be divided into four types: a) myth in the form of gugon tuhon, certain prohibitions which will cause impacts to the person violating them, (b) myth in the form of associative shadows, myth related to dreams, (c) myth in the form of sirikan (prohibitions) that must be avoided, (d) myth in the form of fables, legends and stories. This is believed to have strong legitimacy in people's minds.

Javanese society, in their life cycle, cannot be separated from gugon tuhon. Gugon tuhon can occur in various human life cycles, such as birth, marriage, pregnancy, and death. Gugon tuhon analyzed in this research covers all the cycles, limited to the type of gugon tuhon kang isine sinandi (hidden advice and disguised teachings). The result of their cultural significance is then correlated with Islamic values.

\section{Method}

This research was a case study with ethnography approach. It aimed to describe and explain the form of gugon tuhon in Surakarta and its relevance to Islamic values in the society. The gugon tuhon analyzed were the ones in marriage, pregnancy, and children's education process. This research's place covered in collecting data is in Surakarta, Boyolali, Karanganyar, Wonogiri, Klaten, and Sukoharjo. The sources of data used in this research include documents and informants. The documents used as the source of data are books and manuscripts providing information about gugon tuhon. Verbal data were obtained from several informants through open-interview and note-taking techniques. The informants are residents in the area of research who still know the forms of gugon tuhon. Moleong (2014) explains data analysis techniques, which formally detailing efforts to find themes and formulate hypotheses (ideas) as suggested by the data and support these themes and hypotheses. This study uses qualitative methods with interactive techniques. The interactive technique covers three components: data reduction, data presentation and conclusion drawing (Miles \& Huberman, 2009). Data reduction covers the centralization, simplification (summarizing, coding, tracing according to the theme) of the raw data found during the field's data collection process. The data are then analyzed according to categories and variables. The researchers then draw conclusions and make verification based on the data reduction and the data presentation. The data analysis was conducted by reducing and selecting the data in terms of the gugon tuhon in the Surakarta society. The reduced data were then analyzed by a semantic approach to explain the meaning and 
purposes of gugon tuhon. After that, the analysis of Islamic religion approach was conducted in terms of the urf theory. Terminologically, 'urf refers to a thing that become human habit, and they follow it in terms of popular actions or a word they usually know. This was then used to clarify the gugon tuhon in the urf view, and then the Islamic values in the gugon tuhon was revealed.

\section{Result and Discussion}

\section{Gugon Tuhon Related to Cycles off Marriage}

Javanese people are well aware that marriage is a necessity that must be fulfilled by a person who has grown up and is financially able to meet their household's needs. For Javanese society, marriage is a means to fulfill biological needs and as a means to carry off their descendants. Javanese parents are anxious if their adult children, both boys and girls do not immediately get candidates to be their life partners. In dealing with this issue, apart from worrying about their children's fate in the future, Javanese parents also tend to feel inferior or ashamed of their neighbors or other relatives in their neighborhood. Therefore, most Javanese parents, especially in regencies around Surakarta, such as Boyolali, Sukoharjo, Karanganyar, Klaten and Wonogiri, often urge their adult children to get married immediately.

They argue that getting married, fortune, happiness and blessing will be much easier to get. This is reflected, as in the expression "Nikah ora susah, kepara rejekine tambah" (marriage is not difficult, and will even bring more fortunes). And in the expression "tambah anak tambah rejeki" (more children, more fortune). Both expressions give Javanese people suggestions to be optimistic in their marriage and not be afraid of fortune after getting married and having children. When it comes to marriage, Islam has a similar view. The laws and conditions of marriage and an example of one of the major prophetic sunnah are marriage. This is in line as stated in Q.S. ar-Rum: 21: "And of His signs is that $\mathrm{He}$ created for you from yourselves mates that you may find tranquillity in them; and He placed between you affection and mercy. Indeed, in that are signs for a people who give thought."

This verse clearly demonstrates that Islam wants its people to get married, as did the prophets and apostles. By getting married, a person will feel at ease because their honor and dignity are protected. According to the Islamic view, marriage will actually open the door of fortune from Allah. This is in line with Q.S. an-Nur: 32, "And marry the unmarried among you and the righteous 
among your male slaves and female slaves. If they should be poor, Allah will enrich them from His bounty, and Allah is all-Encompassing and Knowing."

It is evident that a man and woman should not be afraid and wary of fortune when married and later has children. The trend of Javanese people nowadays, different from that of the past, is more worried if they get married, especially at a young age, and then have many children. They consider that it will hinder their fortune and career and cause them to have an unhappy household. Planning for the future is necessary, but it will be inappropriate if the concern causes the person to decide not to get married and have children. In Islam it is clearly stated that humans must always try. By getting married and having children, someone will try to fulfill their household needs through endeavors. It is in those endeavors that God will actually open a path of fortune and provide adequacy.

Regarding the cycle of marriage, both before and during, Javanese parents will also advise on the form of gugon tuhon as shown by the example below:

(1) Calon manten puteri ora ilok yen lelungan dhewe, kudu dipingit pitu utawa patangpuluh dina sadurunge ijab (Source: Ibu Kartini (perias pengantin), 68 tahun, Kecamatan Boyolali, Kabupaten Boyolali).

(Prospective bride should not travel alone. She must be secluded for seven or forty days before the wedding ceremony)

Gugon tuhon is an advice that is often passed down orally by parents to their children who will carry out a wedding ceremony. It is prohibited for Javanese bride and groom, especially bride, to travel alone or take a long trip without their mahram. This prohibition actually has several considerations. If the prospective bride travels or takes a long trip alone, it is feared that something will happen to the candidate, disrupting the wedding plans that have been prepared. It is worth noting that the process of marriage involves many parties. If accompanied by his mahram then the bride is expected to be more safe.

In the cultural context of Javanese society unmarried women are described as very valuable. Their attitudes and behaviors can lead to various perceptions that can influence the judgment of many, both the surrounding community and the male family. For example, a woman travels alone, then accidentally meets and chats with a male friend on the street. It is then witnessed by others who know the woman can potentially trigger unfavorable perceptions, even a woman (Sari et al., 2017). Javanese parents of prospective bride are always careful in advising their daughter to protect her honor and the honor of their family. 
Another thing that is also the reason for the daughter being secluded before marriage is that the bride and groom do not meet for a while, to avoid something undesirable (Karkono et al., 2020). This is actually very relevant to society's current condition, where the relationship among girls and boys is considered increasingly free. The prospective bride and groom have received their parents' agreement, but that does not mean that they are free to establish relationships before the wedding ceremony. It is feared, if not secluded, they both cannot resist their desire and lust.

Gugon Tuhon is also relevant to the teachings in Islam. A woman must be accompanied by her muhrim when traveling/leaving the house, not only at the time of marriage, but applies in any situation. Following the hadith of the Prophet, from Ibn Abbas Radhiyallahu 'anhu, this is narrated: "No man must not be alone with a woman except in the presence of her mahram. No woman should travel except in the company of a mahram." [HR. Imam Bukhari] (Al-'Asqalani VI/172)].

When a woman travels or takes a long trip accompanied by muhrim, it will be more safe for her while also protecting her honor from defamation. The seclusion with someone who is not mahram is prohibited because it will bring them closer to adultery. This is explained in Q.S. al-Isra': 32, "And do not approach unlawful sexual intercourse. Indeed, it is ever an immorality and is evil as a way."

The gugon tuhon in marriage is also related to the selection of month to conduct wedding ceremonies. Javanese society has an astrology system used to determine good and bad days in conducting something. This system is obtained through observation on natural phenomena and similar series events that continuously happen. It implies that the Javanese society believes in the ngelmu titen is an unwritten system but bonding and used as the foundation to determine something mainly related to Javanese cultural activities. There is also the gugon tuhon related to the time for wedding ceremonies as the following.

(2) Aja nggelar palakrama ing sasi sura, mergane wayah kuwi Kraton Segara Kidul lan Kraton Gunung Merapi lagi duwe gawe.

(Do not conduct wedding ceremonies in Sura/Muharram Month becuase in that time, Kraton Segara Kidul and Kraton Gunung Merapi have hajat or ceremonies)

This gugon tuhon indicates the prohibition with the lingual mark of "aja" or "do not" which means prohibition to conduct wedding ceremonies in Sura or Muharram month based on Islamic calendar because it coincides with 
hajat (ceremony) conducted by Keraton Segara Kidul and Keraton Gunung Merapi or known as "duwe gawe" in Javanese term. If the society recklessly conduct a wedding ceremony and do not follow this gugon tuhon, they will get disaster while the wedding ceremony is conducted. This disaster can come to brides and grooms that will have bad lucks in their lives. However, this gugon tuhon contains the moral value of tolerance. It is due to Sura Month is considered holy. Sura Month is the first month in the Islamic calendar, the first month for the society to conduct introspection by reflecting their deeds from the previous year and prepare to increase their worship in the new year. It is expected that the society more focuses on worship in Sura month and delay to conduct ceremonies, for instance wedding ceremonies.

Apart from those reasons, there is another factor related to tolerance value. Sura Month is mourning month for Islamic community, that is the Karbala tragedy when Hussain was killed and Muslim feel lost. The prohibition against conducting wedding ceremonies in Sura Month is to respect Hussain's tragedy in Karbala. Hussain is one of the favourite grandsons of the Prophet Muhammad, so he had ever kissed while crying since he knew that his grandson would be beheaded. Hussain was killed at Muharram 10, and that day is called as Ashura day. As a consequence, muslim are suggested to fast in Ashura day to remember that tragedy. Besides, the virtue of Ashura Fasting as stated by Ibn Abbas who narrate that the Prophet Muhammad truly fast in the Ashura day. In that day, the Prophet Muhammad make a wish to Allah to forgive his sins in the previous year. As stated in Hadits narrated by Muslim "Rasullullah was asked about ashura fasting, he anwered, 'it can erase sins in the previous year." (Sahih Muslim). Thus, the gugon tuhon in data number (2) contain the moral value of tolerance to respect the mourning event of the Prophet Muhammad's family related to Hussain death on Muharram 10, in Karbala.

\section{Gugon Tuhon Related to Pregnancy Cycle}

In addition to the marriage cycle, the pregnancy cycle is also important for Javanese people. In several regions in Indonesia, the pregnancy process receives special attention for the mother and the baby's safety and health through various rituals, prohibitions, and suggestions (Adriana, 2012). Nine months of pregnancy is not an easy thing to go through. Mothers must strive to take care of themselves and the fetus in the womb, both physically and psychologically, to get smooth until the baby is born. Prohibition is usually associated with food consumed by pregnant and lactating women trusted by 
the local community to have its own meaning (Rahadini \& Rahmat, 2018). Besides, the mother also needs to maintain attitudes, actions, and words so that the mother can later reduce her child's good nature. In line with those concepts, Javanese people have a gugon tuhon stating:

(3) Aja seneng ngrasani, utawa nyacad kekurangane uwong, mundhak anake mengko duwe sifat kaya sing dirasani (Ibu Supartini, 65 tahun, Surakarta)

(Do not gossip, denounce or say the shortcomings of others, or consequently your child will have the characteristics you denounce.)

This gugon tuhon employs prohibition sentence using the word aja (don't) followed by mundhak (consequently). The word aja shows prohibition for someone to do something, while mundhak shows the consequence of the prohibition. This gugon tuhon is meant to teach a woman to be careful, especially during pregnancy, with her words by not denouncing others. Though pregnant women are generally more sensitive to something and easier to get upset and angry, they must control her words. The clause 'mundhak anake kaya sing dirasani' makes it easier for the woman to obey the prohibitio, because surely she does not want her child to have the bad things she denounces. In Javanese society there is a concept of life that we will get something according to what we did just like what is expressed in sapa nandur bakal ngundhuh (whoever plants will reap).

Moral values in gugon tuhon of datum (3) are relevant to values in Islamic teachings. In Islam's teachings, a person is not allowed to gossip or denounce others, as stated in Q.S. al-Hujarat: 12, “... And do not spy or backbite each other. Would one of you like to eat the flesh of his brother when dead? You would detest it. And fear Allah..."

This verse clearly suggests that in Islam's teachings, a person is not allowed to denounce the deficiencies or gossip about others' shortcomings. Even in that verse, the prohibition to gossip and denounce applies to anyone, not only for women or in pregnancy. Allah's threat is harsh for those who gossip, that gossiping is like eating the flesh of one's own brother. The habit of gossiping can also negatively impact other things, such as triggering defamation, misunderstanding, and even the emergence of conflict or division. People who are used to gossip tend to see things from a negative perspective, so it is easy to prejudice others. This can ultimately affect the trust of others around him. The aforementioned gugon tuhon is also in line with gugon tuhon in the following datum, only the different expression's origin. 
(4) Wong meteng ora entuk mbatin sing ala-ala, apa meneh yen weruh perkara sing ora disenengi utawa sing disiriki, mundhak nurun ning anake (Ibu Surati, 51 tahun, asal Tulung, Klaten).

A pregnant woman should not denounce bad things, even if not verbalized, especially when seeing something undesirable, so that later it will not impact her child.

Pregnant women tend to be more sensitive especially in the early stages of pregnancy. They tend to have unstable emotions, making it easier to feel angry when experiencing and seeing something they do not like. Meanwhile, in Javanese society's view, a pregnant woman is suggested to often fast and worship. It aims to train the embryo to do so. Fasting essentially means to hold back. Holding back refers to maintaining ourselves in not doing all bad deeds, not following our lust and training self-control. Concerning the gugon tuhon in data number (4), there is a moral message of pregnancy period that a pregnant woman needs to hold back and maintain her lust, especially lust in her heart and mind. Hence, she is suggested not to think bad things because it will make her psychological condition worse that simultaneously affect the embryo. Besides, she is also suggested to increase prayer and reading Quran. It imitates the habit of Zechariah who ask Allah for having a good chold as stated in Q.S. Ali 'Imran: 38, At that Zechariah called upon his Lord, saying, "My Lord, grant me from Yourself a good offspring. Indeed, You are the Hearer of supplication."

Besides a mother who needs to maintain her actions while getting pregnant, a father also needs to maintain his daily life. In the Javanese society, there is a gugon tuhon, as follows.

(5) Yen bojomu lagi ngandhut aja tumindak daksiya marang kewan, aja mateni kewan, aja mbebedak neng alas, lan aja mancing mundhak anakmu mbesuk cilaka.

(While your wife gets pregnant, do not hurt animals, kill animals, hunts in the forest, and fish because your child can be harmed)

This gugon tuhon has relation to the one for pregnant women with the moral value to hold back and maintain behavior. While getting pregnant, parents should become really careful because what they do will affect the embryo. Consequently, in data number (5) is suggested to husbands or fathers to maintain their behavior particularly to animals and living things when their wives are getting pregnant. Husbands or fathers are also suggested to do 
good deeds, multiple worship and charity, so their children will have good personalities. The suggestion to always do good deeds is not also valid while the wives get pregnant, the One Almighty God, Allah, likes people who do good deeds as stated in Q.S al-Baqarah: 195, "And spend in the way of Allah and do not throw (yourselves) with your (own) hands into destructions (by refraining). And do good; indeed, Allah loves the doers of good."

\section{Gugon Tuhon on Children Nurturing Pattern}

In parenting, Javanese people have rules to regulate their lives, so that the child is easy to care for, healthy, physically, mentally, and spiritually, and later becomes a good child by family and public expectations. Therefore gugon tuhon in parenting exists which states;

(6) Bocah cilik aja diajak metu wayah surup (waktu maghrib), mundhak digondhol wewe. (Bapak Sugiman, 63 tahun, Karanganyar)

Kids should not be taken out at sunset, or consequently they will be kidnapped by wewe (female ghost)

Gugon tuhon in datum (6) employs prohibition sentence using the word aja (don't) followed by mundhak (consequently). For Javanese people, wewe is a mythological creature depicted as a woman with long hair and long shagy breasts. In Javanese mythology, wewe kidnapped children who roam in the evening, especially at sunset or dusk. The widely spread narrative myth of wewe is often used by Javanese parents to scare their children and make them comply with the advice. However, the purpose of this gugon tuhon is actually not just to frighten the kids, but also to educate them many values and teachings, namely: Maghrib (sunset) is a change of day and night. At that time the eyes cannot see as clear as in the daytime, so it is worried that children will easily fall down, get lost, and be prone to crimes when they go out. In addition, the changes of the air condition during that may cause bad impacts on their health. (2) Maghrib time is a time for worship, so they are expected to go to the mosque to have Maghrib prayer, rather than playing around. This instills religious education from an early age.

In regards to the mythological symbol of wewe which is believed to be an unseen creature that comes out at night, it turns out to have relevance to the hadith of the prophet. From book of Al-Bukhari hadith no. 3304 and Muslim no. 2012, it was said that Jabir bin Abdillah narrated that the Prophet sallallaahu 'alayhi wa sallam said: "When night falls (or it is evening), keep your children close to you for the devils spread out at that time. But when an 
hour of the night elapses, you can let them free. Close the doors and mention the Name of Allah, for Satan does not open a closed door."

The word جُنْحُ اللَّيّزل (night falls) means early night right after the sun sets. In the book of Muslim there is a hadith (no. 2013) stating: "Do not let your animals and children go out when the sun has set, until the first part of the night is over, for the devils come out when the sun sets, until the first part of the night is over." Imam Nawawi said, "The aim of 'keep your children close to you' is a prohibition so that children do not come out at that time. The words from the Prophet "for the devils spread out at that time" means it is feared that the devils will disturb the children at this time because there are many of them by that time. The ethics of parenting can also be seen from the following datum:

(7) Menawa saka lelungan, aja langsung marani bayi, kudu wijik dhisik, mengko mundhak anake kena sawan.

'When you are home from traveling, do not directly have a contact with a baby. You must first cleanse yourself with water, or consequently the kid will get sawan (convulsions)

This Gugon tuhon also employs prohibition sentence using the word aja (don't) followed by mundhak (consequently) showing the consequences if the prohibition is violated. Parents having children, especially babies, must always maintain hygiene of both the environment and surrounding. It is intended that the babies who are still very sensitive to avoid sawan (convulsions). Javanese parents believe that babies are prone to sawan. Sawan for the Javanese community can mean interference that comes from something invisible that can affect the babies' health, comfort, or safety. For modern society, sawan could actually be dirt, bacteria, viruses, or things that can cause illness to people who contact the carrier. However, for Javanese people, sawan is more considered as the interference of spirits.

This is based on interviews with an informant named Mr. Gito (71), a village elders in Boyolali. Sawan can be carried by someone who can then be transmitted to others. It can also refer to the form of interference from spirits. For Javanese people, infants are considered vulnerable to such convulsions. The consequences of exposure to sawan can be in the form of illness or being fussy (crying constantly because of something that is not clear). To prevent this from happening, someone who will contact the baby is instructed to cleanse themselves first. In addition, another efforts to avoid convulsions is by not taking the baby out at night. 
In regard to the suggestion or advice to maintain hygiene, Islam also teaches followers to always keep cleanliness. There are even various ways and reasons that require someone to cleanse. Cleansing related to this context can be done by washing hands and feet with water. Logically after washing, the body will be clean and will not transmit dirt or germs that may be carried from the outside when touching something.

Closely observed, the structure of the sentence in the expression of gugon tuhon has a distinctive characteristic. It contains the expression of command accompanied by the consequences of violation. Rationally, the causal aspects often have no significant relationship. However, Javanese people believe that this aspect can be suggestive and useful for children to easily grasp and obey the real essence of advice. Gugon tuhon, thus, has its own purposes and functions. From some aforementioned data of gugon tuhon in Surakarta and its surrounding areas, it can be understood that gugon tuhon have their own purposes and functions in its disclosure. These functions include as a medium for Javanese parents in instilling ethical values, moral values, manners, and maintaining dignity in behaving in society. The existence of gugon tuhon is indirectly able to construct children's character always to obey parents' advices. It is similar to Nanda (2020) related moral values in the tradition of carrying babies at maghrib time (sunset prayer time). This gugon tuhon and tradition contains a moral value and good purpose in terms of responsibility to take care of own children. In this data, the gugon tuhon is also related to the prohibition to go out in the night to indirectly discipline children not to play too much in the night becuase it is for taking a rest and saving energy for tomorrow's lesson. It is useful for the character education facility to children to be accustomed to do good deeds.

The gugon tuhon also becomes the facility to conduct control on society's attitudes. Moral values in terms of tolerance, always doing the goods, mutual respect, and mutual protection in the gugon tuhon should be implemented to construct a harmonious social life. Besides, the society will indirectly be more careful in doing something as their minds are implanted that what they do is what they will get. Still, the gugon tuhon recognized in the society is mostly affected by ancient traditions inherited by generations without a clear theorem. If there are good implications and effects on society and not beyond Islamic sharia, that will not become a problem. As suggested by Kholik (2019), as long as what society believes in is not contradicting Islamic lessons, it will be accepted by Islamic sharia and law. 


\section{Conclusion}

Gugon tuhon is one of the forms of Javanese oral tradition. It is a legacy of the ancestors that is still widely used and trusted by the Javanese society, including Surakarta. Gugon tuhon is essentially more than just verbal utterances passed down across generations, as it has cultural values relevant to ethical, health, and Islamic values. There are some gugon tuhon related to life cycles, such as marriage, pregnancy, birth, and parenting. Some other are related to activities and habits in daily life. By exploring the cultural values in the tradition of gugon tuhon it is expected that these forms can be seen as cultural richness that can be addressed and applied wisely in people's lives, especially in Surakarta. The existence of gugon tuhon is possibly used as the character education facility to young generation to construct good habits. Besides, the gugon tuhon also functions as the facility to implant Islamic moral values such as tolerance, responsibility, and always doing the goods to construct a harmonious life system.

\section{References}

Adriana, I. 2012. Neloni, Mitoni atau Tingkeban: Perpaduan antara Tradisi Jawa dan Ritualitas Masyarakat Muslim. KARSA: Journal of Social and Islamic Culture, 19(2), 238-247.

Ali, M. 2011. Muslim diversity: Islam and local tradition in Java and Sulawesi, Indonesia. Indonesian Journal of Islam and Muslim Societies, 1(1), 1-35.

Andariati, L. 2019. Relevansi Mitos Kali Pemali Dengan Etika Lingkungan Islam. Jurnal SMART (Studi Masyarakat, Religi, Dan Tradisi), 5(2), 275-289.

Ekowati, V. I. 2008. Tata Cara Dan Upacara Seputar Daur Hidup Masyarakat Jawa Dalam Serat Tatacara. Diksi, 15(2), 204-220.

Fitri, A. Z. 2012. Pola Interaksi Harmonis antara Mitos, Sakral, dan Kearifan Lokal Masyarakat Pasuruan. El Harakah (Terakreditasi), 14(1), 1-17.

Indana, N., Makmun, M. A., \& Machmudah, S. 2019. Tradisi Ruwah Desa dan Implikasinya Terhadap Pengetahuan Tauhid Masyarakat Dusun Ngendut Kesamben Ngoro Jombang. Tafáqquh: Jurnal Penelitian Dan Kajian Keislaman, 7(2), 81-104. 
Kamilah, N., \& Setyani, T. I. 2018. The Mystical Elements in Javanese Short Stories as a Local Wisdom Manifestation. IOP Conference Series: Earth and Environmental Science, 175(1), 12064. IOP Publishing.

Karkono, K., Maulida, J., \& Rahmadiyanti, P. S. 2020. Budaya Patriarki Dalam Film Kartini (2017) Karya Hanung Bramantyo. Kawruh: Journal of Language Education, Literature, and Local Culture, 2(1).

Kholik, K. 2019. Mitos-Mitos Penghalang Perkawinan Pada Adat Jawa Dalam Prespektif Hukum Islam. Usratuna: Jurnal Hukum Keluarga Islam, 2(2), $1-26$.

Kurniawati, D., \& Widhyasmaramurti, W. 2019. Pragmatic Meaning of Baby Care Gugon Tuhon in Javanese. International Review of Humanities Studies 4(2), 973-986.

Miles, B. M., \& Huberman, A. M. 2009. Qualitative Data Analysis (Transl. Tjejep Rohandi Rosidi. Analisis Data Kualitatif: Buku Sumber Tentang Metode-metode Baru). Ul Press

Moleong, L. J. 2014. Metodologi Penelitian Kualitatif. Remaja Rosda Karya.

Muraina, M. B. 2015. Oral Tradition as a Reliable Source of Historical Writing: Arguments for and Against and Implications for Historical Writing in Education. Oral Tradition, 22.

Nanda, A. A. N. 2020. Pendidikan Moral Pada Tradisi Bayi Digendong Saat Maghrib di Desa Regunung-Jawa Tengah. Criksetra: Jurnal Pendidikan Sejarah, 9(1), 72-81.

Nurdin, A. 2016. Integrasi Agama dan Budaya: Kajian Tentang Tradisi Maulod dalam Masyarakat Aceh. El Harakah (Terakreditasi), 18(1), 45-62.

Poerwadarminta, W. J. S. 1939. Baoesastra Djawa. Wolters.

Rahadini, A. A., \& Rahmat, R. 2018. Philosophical meaning of the myth of pregnant and nursing mothers at Dawuhan village, Banyumas. EduLite: Journal of English Education, Literature and Culture, 3(2), 188-195.

Roibin, R. 2010. Agama dan mitos: Dari imajinasi kreatif menuju realitas yang dinamis. El-Harakah, 12(2), 85-97.

el Harakah Jurnal Budaya Islam Vol. 22 No. 2 Tahun 2020 
Sari, T. M., Rosyid, A., \& Romli, R. 2017. Perkawinan Adat Jawa Perspektif Hukum Islam di Desa Terlangu Kecamatan Brebes. Al-Mashlahah: Jurnal Hukum Islam dan Pranata Sosial Islam, 5(10), 805-824.

Setyawan, B. W., \& Saddhono, K. 2017. Eret traditional ceremony as representation of spirit of mutual cooperation among coastal communities. Advanced Science Letters, 23(10). https://doi.org/10.1166/asl.2017.10363

Soehardi, S. 2002. Nilai-Nilai Tradisi Lisan dalam Budaya Jawa. Humaniora, 14(3), 11972.

Subalidinata, R. S. 1968. Sarining Kasusastran Djawa. Jaker.

Sundari, S. 2018. Gugon Tuhon Jawa in Kismorejo Village, Jaten District, Karanganyar District, Java Tengah Province (Literature Reception Study). International Seminar on Recent Language, Literature, and Local Cultural Studies (BASA 2018). Atlantis Press.

Taruna, M. M. 2016. Shifting The Myth in The Middle of Social Change (Mythological Studies in Kiskendo Cave and Betetor Hamlet in Kendal). Jurnal SMART (Studi Masyarakat, Religi, Dan Tradisi), 2(01), 67-80.

Wahyuni, I. 2018. Menguak Mitos Tahun Duda dari Catatan Pernikahan Perspektif Hukum Islam di Kabupaten Pati. An-Nidzam: Jurnal Manajemen Pendidikan dan Studi Islam, 5(1), 139-165. 